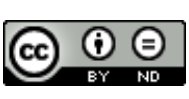

PAWE $Ł$ KOWALSKI

MARCIN FASTYN, JAKUB BANASIAK (Instytut Slawistyki Polskiej Akademii Nauk)

\title{
WYKORZYSTANIE ZASOBÓW BIBLIOGRAFICZNYCH PRZEZ INSTYTUCJE KULTURY CZY ICH INTEGRACJA (NA PRZYKŁADZIE SYSTEMU ISYBISLAW)
}

\section{Słowa kluczowe}

baza bibliograficzna; system informacyjno-wyszukiwawczy; instytucja kultury; iSybislaw

Paweł Kowalski, Doktor nauk humanistycznych w zakresie językoznawstwa (filologia słowiańska). Adiunkt w Instytucie Slawistyki Polskiej Akademii Nauk. Zajmuje się językami Słowiańszczyzny południowej, słowotwórstwem, terminologią językoznawczą, językami mniejszościowymi i językami informacyjno-wyszukiwawczymi.

E-mail: kowalion@wp.pl

ORCID ID: 0000-0001-6459-2621

Marcin Fastyn. Doktor nauk humanistycznych w zakresie językoznawstwa (filologia słowiańska). Adiunkt w Instytucie Slawistyki Polskiej Akademii Nauk. Zajmuje się językami południowosłowiańskimi, językiem Stanisława Lema, teorią przekładu, leksykologią, słowotwórstwem i onomastyką.

E-mail: avtandil83@gmail.com

ORCID ID: 0000-0003-4726-476X

Jakub Banasiak. Doktorant w Instytucie Slawistyki Polskiej Akademii Nauk. Zainteresowania badawcze: językoznawstwo konfrontatywne (zwłaszcza bułgarsko-polskie), składnia, semantyka, języki i systemy informacyjno-wyszukiwawcze.

E-mail: jakubbanasiak@o2.pl

ORCID ID: 0000-0002-7319-0736 


\section{Keywords}

bibliographic database; information retrieval system; cultural institution; iSybislaw

\section{Streszczenie}

W artykule przedstawiono refleksję nad stanem i perspektywami współpracy między twórcami współczesnych bibliografii w środowisku cyfrowym a instytucjami kultury, takimi jak: wydawnictwa, biblioteki, repozytoria, archiwa. Wskazano perspektywy i rozwiązania wybranych problemów dotyczących współpracy między tymi podmiotami na przykładzie tworzonego w Instytucie Slawistyki PAN systemu informacyjno-wyszukiwawczego iSybislaw. Zasoby informacyjne systemu wykorzystywane są w wydawnictwach naukowych (Wydawnictwo Instytutu Slawistyki PAN), różnego typu repozytoriach tekstów pisanych i mówionych, bibliotekach i portalach instytucjonalnych. Omówione zostały modele integracji tych zasobów. Rozważania prowadzą do wniosków, że obecnie, gdy coraz więcej bibliografii funkcjonuje w środowisku cyfrowym, konieczna jest ścisła współpraca i integracja z instytucjami kultury. Pozwala ona zwiększyć grono odbiorców informacji bibliograficznej, która stanowi skarbnicę wiedzy i dziedzictwa kulturowego. W przypadku systemu iSybislaw dzięki integracji zwiększa się grono odbiorców tematów i nurtów związanych z badaniami wszystkich języków słowiańskich. W zastosowanym w systemie języku słów kluczowych możliwe jest pokazanie bogactwa terminologii we wszystkich językach słowiańskich, rozwoju slawistyki na przestrzeni dziejów, trendów we współczesnej Słowiańszczyźnie. Związków - coraz szerszych - językoznawstwa z innymi naukami, w tym m.in. z antropologią, socjologią, psychologią, historią, nauką o literaturze, kulturoznawstwem.

\section{Summary}

\section{Using bibliographic resources by cultural institutions or their integration (example of the iSybislaw system)}

The article reflects on the state of and perspectives for cooperation between creators of contemporary bibliographies in digital environment and cultural institutions, like publishing houses, libraries, repositories, archives. The text points out perspectives and chosen problems solutions concerning cooperation between these entities, using the example of the information retrieval system iSybislaw, created by the Institute of Slavic Studies, Polish Academy of Sciences. Information resources of the system are used by scientific publishers (Publishing House of the Institute of Slavic Studies, Polish Academy of Sciences), various types of repositories of written and oral texts, libraries, and institutional portals. The article describes models of integrating these resources. Deliberations led to the conclusion, that nowadays, when growing number of bibliographies work in digital environments, there is a need for close cooperation and integration with cultural institutions. It would lead to broadening the circle of recipients of bibliographic information, which is a treasury of knowledge and cultural heritage. In the case of the iSybislaw system, integration led to growing number of recipients of topics and trends connected with studies of all Slavic languages. The keywords language used in the system enabled presentation of richness of termi- 
nology in all Slavic languages, historical development of Slavic studies, trends in contemporary Slavic territory, as well as growing connections between linguistics and other sciences, e.g. anthropology, sociology, psychology, history, literary studies, cultural studies.

\section{Uwagi wstępne}

D) ynamiczne zmiany w zakresie tworzenia bibliografii obserwowane od kilkunastu lat związane są nierozerwalnie z przeobrażeniami uprawiania współczesnej nauki. Twórczość naukowa coraz częściej przenoszona jest do środowiska cyfrowego - bądź też od razu powstaje w formie cyfrowej - a papier, do tej pory nieodłączny element i nośnik badań humanistycznych, schodzi na plan dalszy; wkrótce może być zupełnie wyparty przez nowoczesne narzędzia cyfrowe, pełniące funkcje środków przekazu nowej generacji. Tradycyjne bibliografie w postaci papierowej odchodzą więc do przeszłości, a w ich miejsce tworzone są mniej lub bardziej złożone bazy bibliograficzne, często w postaci systemów informacyjno-wyszukiwawczych. Mimo oporu części środowiska naukowego wobec tych zmian, wydają się one nieuniknione, a proces cyfryzacji nauki nie do zatrzymania. Otwiera to nowe możliwości przed twórcami nowoczesnych bibliografii. Pojawiają się perspektywy, które dotąd były niedostępne (czy wręcz niemożliwe do osiągnięcia), tak dla pojedynczych użytkowników, jak i dla instytucji nauki oraz kultury.

Wychodząc od ogólnych definicji instytucji kultury, w których zazwyczaj uwypuklana jest rola upowszechniania, promowania i zachowania (przechowywania i rewitalizacji) kultury w społeczeństwie, w artykule zostanie przedstawiona refleksja nad stanem i perspektywami współpracy między twórcami współczesnych bibliografii w środowisku cyfrowym a instytucjami kultury, takimi jak: wydawnictwa, biblioteki, repozytoria i archiwa ${ }^{1}$. Celem jest wskazanie perspektyw i rozwiązań wybranych problemów dotyczących współpracy między tymi podmiotami; między instytucją, w której tworzona jest bibliografia naukowa, a instytucjami szeroko rozumianej kultury. Te ostatnie utożsamiamy z podmiotami promującymi dziedzictwo kultury (dziedzictwo kulturalne), czyli z tymi, które dbają o zachowanie pamięci o zasobach rzeczy materialnych i niematerialnych ${ }^{2}$.

${ }^{1}$ O kulturze i instytucjach kultury zob. np. A. Kłoskowska, Socjologia kultury, Warszawa 2007.

2 Por. m.in. T. Szlendak, J. Nowiński, P. Wieczorek, Podręcznik szkoleniowy dotyczący sektora kultury w Polsce dla wnioskodawców i partnerów Programu „Promowanie 
Koncentrujemy się w tej pracy na tworzonym w Instytucie Slawistyki PAN systemie informacyjno-wyszukiwawczym iSybislaw, który dostępny jest w otwartym dostępie w Internecie: www.isybislaw.ispan.waw.pl. Jego zasoby informacyjne wykorzystywane są w wydawnictwach naukowych (Wydawnictwo Instytutu Slawistyki PAN), różnego typu repozytoriach tekstów pisanych i mówionych, bibliotekach i portalach instytucjonalnych. W artykule chodzi nam także o pokazanie pewnego modelu integracji zasobów bibliograficznych z instytucjami kultury, wykorzystania w systemie iSybislaw dorobku i pracy - a przede wszystkim zasobów - tych instytucji, nie wchodząc w szczegółowe rozważania nad językami informacyjno-wyszukiwawczymi i nad wybranymi zagadnieniach kompletności opisu w ramach takich systemów ${ }^{3}$. Jak pisze bowiem Jadwiga Woźniak-Kasperek:

„Obecnie zbyt często dyskusję o społecznym, w tym naukowym, znaczeniu i funkcjonowaniu bibliografii zastępuje dyskusja o - skądinąd ważnych - kwestiach takich jak na przykład standardy i kompletność opisu, formaty, typ stosowanego języka informacyjnowyszukiwawczego. Coraz więcej bibliografii jest digitalizowanych lub pierwotnie tworzonych w środowisku cyfrowym, mimo to dotkliwie odczuwa się brak integracji tych i innych typów zasobów elektronicznych. Jak ogarnąć to bogactwo? Co zrobić, żeby na czas wykorzystać szanse i ominąć zagrożenia?"4

Te pytania natury ontologicznej stanowią punkt wyjścia naszych rozważań. Digitalizacja powoduje, że ogrom powstałych kiedyś prac jest dostępny większej liczbie odbiorców, a tworzone obecnie szybciej trafiają do użytkowników niż jeszcze kilkanaście lat temu. Skrócony zostaje czas między ukończeniem pracy, jej pojawieniem się w obiegu naukowym, a recepcją przez potencjalnego odbiorcę. Tym samym usprawnia się przepływ informacji w środowisku naukowym, przyspiesza komunikacja naukowa, co wpływa na kształt nauki, w tym formę dyskursu naukowego. Jednocześnie nie znika potrzeba indeksowania powstających prac w zbiorach i zasobach bibliograficznych, które z jednej strony mają dostarczyć potrzebnej informacji ich użytkownikom, z drugiej zaś zachować

różnorodności kulturowej i artystycznej w ramach europejskiego dziedzictwa kulturowego" finansowanego z funduszy EOG 2009-2014, Warszawa 2012.

${ }^{3}$ Spis prac poświęconych tej problematyce znajduje się m.in. na stronie Centrum Slawistycznej Informacji Naukowej: http://isybislaw.ispan.waw.pl/start/mp.htm

4 J. Woźniak-Kasperek, Bibliografia $w$ cyfrowej przestrzeni informacyjnej, „Studia z Filologii Polskiej i Słowiańskiej”, 49, 2014, s. 15-16. 
pamięć o nauce, a szerzej kulturze, dla przyszłych pokoleń. Powoduje to, że indeksatorzy opracowujący rekordy i tworzący bazy bibliograficzne zmuszeni są do zręcznego lawirowania między jakością a ilością dostarczanej informacji: „To build a bibliographic database always requires decisions between quality and quantity. You may describe each publication by a very rich set of metadata and include classifications, citation links, abstracts etc. - or restrict it to the minimum: authors, title, and publication venue"s.

Kompromis między tymi dwoma zmiennymi jest konieczny, bowiem idea kompletności bazy bibliograficznej przy rosnącej i powszechnie udostępnianej produkcji naukowej jest w zasadzie nie do osiągnięcia. Bez zbytniej przesady można napisać, że bibliografia to niekończąca się praca. Co jednak zrobić, by ta praca docierała do coraz większej liczby osób, by nowoczesne systemy informacyjno-wyszukiwawcze, w które przeobraziły się niektóre tradycyjne bibliografie, spełniały pokładane w nich oczekiwania; były atrakcyjne dla swych odbiorców, stanowiły źródło odpowiedzi na nurtujące pytania naukowe i źródło inspiracji do dalszych poszukiwań? Szukanie rozwiązań tych problemów to podążanie za ideą złotego środka (w wypadku systemu iSybislaw świętego Graala slawistycznej informacji naukowej).

\section{Humanistyka cyfrowa a slawistyka cyfrowa}

Poruszane w artykule zagadnienia wchodzą w zakres szeroko rozumianej humanistyki cyfrowej (HC), która we współczesnym dyskursie naukowym (akademickim) zyskuje dużą popularność. Termin ten pojawia się w wielu współczesnych opracowaniach, monografiach, artykułach, czy wystąpieniach konferencyjnych i coraz chętniej używany jest przez samych badaczy w terminologii naukowej. Pomimo wielości opracowań poświęconych HC wśród naukowców nadal istnieją rozbieżności w jej definiowaniu. Przede wszystkim nie jest ustalony jej status, a pytania, czy należy postrzegać ją jako odrębną dyscyplinę (ku czemu skłaniają się badacze zagraniczni), paradygmat badawczy czy nurt badań (niezdecydowanie widać w dyskusji nad humanistyką cyfrową tak w środowisku krajowym, jak i zagranicznym), pozostają cały czas aktualne. Samo pojęcie HC pozostaje więc niedookreślone i wielopłaszczyznowe, a dokładne odpowiedzi na te pytania i zgodność środowiska są na razie raczej niemożliwe. Wspólnym

${ }^{5}$ M. Ley, P. Reuter, Maintaining an Online Bibliographical Database: The Problem of Data Quality, "Extraction et gestion des connaissances", 6, 2006, vol. 2, s. 5-10. 
mianownikiem większości definicji HC jest uwypuklanie roli narzędzi cyfrowych w prowadzonych badaniach humanistycznych. Wychodząc więc od założeń wielokategorialności i wielocechowości pola semantycznego humanistyki cyfrowej ${ }^{6}$, zasadnym jest mówienie o systemie iSybislaw w kontekście szeroko pojmowanej HC, a węziej - slawistyki cyfrowej. Jak pokazały badania różnorodnych, wielojęzycznych definicji terminu HC może być on traktowany inkluzywnie w stosunku do terminu slawistyka cyfrowa. Slawistyka cyfrowa oddaje bowiem lepiej - i co najważniejsze bardziej precyzyjnie -charakter idei, której głównym przedmiotem jest system bibliografii światowego językoznawstwa slawistycznego w środowisku cyfrowym.

System iSybislaw prezentuje bibliografię światowego językoznawstwa slawistycznego, która od początku lat 90. tworzona była w Instytucie Slawistyki PAN i wydawana w wersji papierowej jako wydawnictwo samoistne. W 2007 r. została przekształcona w system informacyjno-wyszukiwawczy iSybislaw dostępny bez ograniczeń w Internecie. Idea systemu została po raz pierwszy zaprezentowana szerszemu gronu naukowemu na XII Międzynarodowym Kongresie Slawistów w Krakowie w roku 19987. W pracach nad rozbudową zbioru informacyjnego systemu, który obecnie liczy ponad 23 tys. pełnych opisów dokumentów (rekordów) bierze udział międzynarodowy zespół językoznawców slawistów z różnych krajów słowiańskich i państw spoza kręgu Słowiańszczyzny.

W 2014 r. w istotny sposób została udoskonalona funkcjonalność bazy bibliograficznej; do opisu bibliograficznego (formalnego i rzeczowego) dołączono możliwość dodawania pełnych tekstów. Ta na pozór drobna zmiana otworzyła nowy rozdział w rozwoju innowacyjnym systemu iSybislaw. Realizacja całego przedsięwzięcia wymaga obecnie współpracy z różnymi instytucjami kultury: wydawnictwami, bibliotekami oraz jednostkami gromadzącymi i udostępniającymi teksty.

\section{Zasoby bibliograficzne a instytucje kultury}

Zasoby bibliograficzne stanowią cenne źródła dla takich instytucji kultury, jak wydawnictwa, biblioteki, repozytoria i inne. Między tymi wyodrębnionymi

${ }^{6}$ M. Przastek-Samokowa, Czym jest humanistyka cyfrowa? Pole semantyczne pojęcia (zarys), „Zagadnienia Informacji Naukowej. Studia Informacyjne” 2016, z. 2, s. 82-93.

7 B. Bojar, Z. Rudnik-Karwatowa, Koncepcja nowoczesnego systemu informacji slawistycznej, [w:] Językoznawstwo: prace na XII Międzynarodowy Kongres Slawistów w Krakowie 1998, Warszawa 1998, s. 41-47. 
elementami wyróżnić można dwie podstawowe relacje. Jedna to ta, w których instytucja kultury wykorzystuje zasoby bibliograficzne zgromadzone w bazie, druga taka, w której to twórcy bazy bibliograficznej wykorzystują zasoby i osiągnięcia (wytwory materialne) instytucji kultury. Schematycznie można te dwie relacje ukazać następująco:

1. instytucje kultury (wydawnictwa i biblioteki) $\leftrightarrow$ iSybislaw,

2. $\quad$ iSybislaw $\leftrightarrow$ instytucje kultury (wydawnictwa i biblioteki)

Przedstawione schematy ilustrują pewien ogólny model obopólnego wykorzystania oraz integracji zasobów bibliograficznych i wytworów instytucji kultury. Przeniesienie tradycyjnych bibliografii do przestrzeni cyfrowej, która stała się nowym miejscem funkcjonowania zasobów bibliograficznych i instytucji kultury (miejscem przecięcia się działań tych obydwu podmiotów), umożliwia stworzenie swoistej wielokierunkowej sieci relacji, którą wpisać można w czworokąt: dokument - wydawnictwo - baza bibliograficzna (system iSybislaw) - użytkownik (transfer informacji, wiedzy). W obrębie takiej sieci możliwy jest transfer wiedzy z jednego elementu sieci do elementu drugiego, z jednego punktu sieci do drugiego. Wszystkie elementy (podmioty) zaangażowane są w tworzenie siatki relacji i współpracy, a każdy z nich jest potrzebny do sprawnego i efektywnego funkcjonowania całościowego sieci powiązań.

W obrębie dwóch wyodrębnionych przez nas relacji występuje szereg zależności i połączeń między ujmowanym materialnie dokumentem udostępnianym przez wydawnictwo, które najczęściej wprowadza także w swoim środowisku cyfrowym charakterystykę słowną danego dokumentu, systemem iSybislaw, wprowadzającym bardziej rozbudowane metainformacje dotyczące dokumentu w postaci charakterystyki wyszukiwawczej dokumentu, a użytkownikiem, który może być potencjalnym odbiorcą wszystkich przetworzonych danych. Powstaje więc specyficzna sieć współrzędnych relacji i w ten sposób dochodzi do kształtowania się mapy (bądź map) wiedzy, po której użytkownik może się dowolnie poruszać, płynnie przechodząc z jednego źródła do drugiego. Wprowadzenie tego typu sieciowości jest wynikiem funkcjonowania wszystkich podmiotów w środowisku cyfrowym, które charakteryzuje m.in. hipertekstualność i multimedialność.

Prześledźmy funkcjonowanie takiej siatki relacji na przykładzie włączania do obiegu bibliograficznego informacji o badaniach lingwistycznych poświęconych mniejszościom narodowym. Posłużymy się przykładem słoweńskiej mniejszości zamieszkującej kilka wsi na terenie Węgier w komitacie Vas, w trójkącie granicznym Węgier, Austrii i Słowenii. Są to Słoweńcy porabscy. Badania nad mniejszością słoweńską na Węgrzech prowadzone są głównie w ośrodkach na- 
ukowych w Mariborze i Lublanie, a także w Budapeszcie. O mniejszości powstają prace naukowe (artykuły i monografie). Są one publikowane w czasopismach tematycznych i udostępniane w Internecie (mogą być udostępniane na stronie internetowej czasopisma, w repozytoriach lub bibliotekach). Powstałe prace zostają zindeksowane w systemie bibliograficznym, w którym udostępniany jest pełen opis bibliograficzny (podawany w ramach charakterystyki wyszukiwawczej dokumentu, wraz z pozostającymi poza charakterystyką wyszukiwawczą dokumentu, a wchodzącymi w zakres metainformacji, abstraktami i streszczeniami). Utworzona metainformacja odnosząca się do poszczególnych dokumentów trafia więc do sieci za pośrednictwem bibliografii. Z bibliografii korzystają różni użytkownicy: przede wszystkim naukowcy, slawiści, słoweniści i inne osoby zainteresowane daną tematyką, którzy poprzez podane metainformacje mogą dotrzeć do wybranych prac. Prace te mogą być w dalszej kolejności wykorzystywane i przetwarzane w artykułach i monografiach naukowych lub w opracowaniach popularyzujących naukę, również takich przeznaczonych dla szerszej społeczności (wykraczających poza hermetyczne środowisko naukowe). W ten sposób otwiera się możliwość wykorzystania zasobów bibliograficznych poza środowiskiem naukowym i wspólne wzbogacanie (wspieranie) powstałego produktu.

W obrębie samej bibliografii - w środowisku wewnętrznym - w opisie treściowym dokumentów poświęconych tej słoweńskiej mniejszości narodowej wprowadzane jest słowo kluczowe Słoweńcy porabscy (por. także opisy innych mniejszości, jak Chorwaci molizańscy/moliscy, Bułgarzy banaccy i in.). Dzięki środowisku cyfrowemu jest ono powiązane z innymi dokumentami poświęconymi tej mniejszości (powiązania z czasem/wiekiem, nazwiskami osób związanych z tą mniejszością, z działaczami społecznymi, kultury i innymi, także z lokalizacją, jak np. Węgry w przypadku mniejszości słoweńskiej Słoweńców porabskich, zaś w przypadku Chorwatów molizańskich Włochy).

Inną grupą etniczną, która może skorzystać na cyfryzacji slawistyki są Kaszubi - baza iSybislaw ma już blisko 200 rekordów, odnotowujących artykuły poświęcone ich językowi, zaś wyniki badań, prowadzonych choćby przez dr hab. Nicole Dołowy-Rybińską z Instytutu Slawistyki PAN są udostępnione czytelnikom na elektronicznej platformie czasopism Instytutu, w repozytorium slawistyki cyfrowej iReteslaw oraz na portalu Academia.edu. W tak pomyślanej sieci powiązań mamy swobodny przepływ wiedzy pomiędzy różnymi instytucjami dziedzictwa kulturowego, zaś bibliografia (obecnie w postaci cyfrowego systemu informacyjno-wyszukiwawczego) jest zarówno biorcą tej wiedzy, jak i jej dawcą. Tworzy się więc wspomniana już swoista mapa wiedzy poświęcona danej 
mniejszości, wykorzystująca naukowe interdyscyplinarne ujęcie, a użytkownik odwiedzający nowoczesną bibliografię może swobodnie się po niej poruszać.

Wypada więc zgodzić się ze słowami Jadwigi Woźniak-Kasperek, która pisze, że „z jednej strony bibliografie służą celom utylitarnym, umożliwiają lub co najmniej ułatwiają osobom zainteresowanym dotarcie do właściwych publikacji (lub - jak dziś częściej je nazywamy - obiektów informacyjnych), pośredniczą między informacją o obiekcie a potencjalnym odbiorcą, użytkownikiem, umożliwiają identyfikację, rozpoznanie obiektu i zaspokojenie doraźnych potrzeb informacyjnych", lecz mają też odmienne zadanie, ponieważ:

„Są skarbnicami pamięci, obrazem stanu szeroko rozumianej kultury w określonym czasie i miejscu, dokumentem, który ma znamiona dokumentu archiwalnego przeznaczonego do zachowania dla przyszłych pokoleń. Dziś zbyt często traci się z pola widzenia to zadanie historyczno-archiwizacyjne, a sprowadza się bibliografię do (bardzo ważnej, ale nie jedynej czy najważniejszej) roli narzędzia informacyjno-wyszukiwawczego." $"$

Dopełniając tę myśl, należy napisać, że dziś bibliografie stanowią integralną część instytucji kultury; mogą być postrzegane jako nośnik informacji kulturalnej. Dzięki podejmowanym przez naukę tematom nie są one oderwane od kultury materialnej i duchowej.

Warto podkreślić również nowe możliwości wykorzystania działalności (pracy) instytucji kultury w bazach bibliograficznych. Jak już zostało wspomniane powyżej, przełomem we współpracy z instytucjami kultury (wydawnictwami naukowymi, portalami wydawniczymi, witrynami czasopism, platformami czasopism i repozytoriami) było umożliwienie w 2014 r. dodawania do opisu bibliograficznego (rekordu w systemie informacyjno-wyszukiwawczym) pełnych tekstów. Teksty te są dostępne albo poprzez odsyłające linki, wtedy bezpośrednio kierują użytkownika do strony (portalu) danego wydawnictwa, albo zamieszczane na serwerze w Instytucie Slawistyki PAN, na którym posadowiony jest system iSybislaw. Jak pokazuje praktyka osób indeksujących, większość udostępnianych tekstów wykorzystuje pierwszą możliwość, czyli najczęściej zamieszczane są linki do platform wydawnictw lub tworzonych specjalnych platform czasopism, jak np. platforma ISS PAS Journals, na której wszystkie czasopisma Instytutu Slawistyki są w wolnym dostępie.

8 J. Woźniak-Kasperek, dz. cyt., s. 16.

9 Tamże, s. 16. 


\section{Zasoby bibliograficzne a otwarty dostęp w nauce}

Począwszy od przełomu XX i XXI w. rośnie popularność ruchu Open Access, którego działania związane są z otwieraniem zasobów nauki. Zarysowuje się różnorodna polityka wydawnicza czasopism i wydawnictw naukowych przy poszczególnych jednostkach naukowych. Wyróżnić można 4 podstawowe modele: a) udostępnianie pełnych tekstów w postaci oddzielnych plików PDF każdego artykułu; b) udostępnianie pełnych tekstów w postaci jednego pliku ze wszystkimi artykułami z danego czasopisma lub z danej pracy zbiorowej; c) udostępnianie abstraktów i spisów treści poszczególnych zeszytów oraz d) udostępnianie samych tytułów prac w konkretnych zeszytach. Pomijamy tutaj model 5, czyli brak jakiejkolwiek informacji dotyczącej zawartości zeszytów na portalu wydawnictwa lub gdziekolwiek w sieci. Na szczęście taka praktyka staje się już rzadkością.

Przyjrzenie się poszczególnym czasopismom językoznawczym dobrze obrazuje te 4 modele. Słoweńskie czasopismo „Slavia Centralis” prezentuje model 1, czyli otwarty dostęp do pełnych tekstów w postaci oddzielnych plików PDF dla każdego artykułu, które mogą być linkowane przy każdym szczegółowym opisie dokumentu. Jest to niezwykle użyteczne i wygodne przy tworzeniu rekordów bibliograficznych dla indeksatorów. Także z perspektywy użytkownika takie rozwiązanie jest korzystne, ponieważ dołączony link do rekordu w bazie odsyła od razu do pełnego tekstu dokumentu. Model ten został wdrożony w Instytucie Slawistyki PAN w ramach projektu Indeks plus - wszystkie czasopisma instytutowe zostały zdigitalizowane i udostępnione na platformie cyfrowej w wolnym dostępie. Numery prezentowane są wraz z pełnym spisem treści, a każdy tytuł pracy odsyła do oddzielnego dokumentu w postaci pliku PDF. Przykład realizacji modelu 2 prezentuje słowackie czasopismo „Slovenská reč”. W Internecie dostępne są wszystkie teksty od roku 1932. Udostępniane są całe zeszyty w jednym pliku PDF. Rozwiązanie to jest dla użytkownika nieco mniej wygodne, ponieważ po otworzeniu pliku musi jeszcze wyszukać odpowiednie strony szukanego artykułu. Model 3 reprezentuje polskie czasopismo językoznawcze „Język Polski. Pismo Towarzystwa Miłośników Języka Polskiego”. Redakcja czasopisma udostępnia na swojej stronie abstrakty wszystkich artykułów oraz spisy treści poszczególnych zeszytów. Warto tutaj dodać, że zeszyty czasopisma od rocznika I (1913) do LXXXIX (2009) są dostępne bezpłatnie w Małopolskiej Bibliotece Cyfrowej, gdzie wpisują się w model 2 (udostępnianie całych zeszytów w postaci jednego pliku). Zeszyty czasopisma z lat 2010-2016 
dostępne są odpłatnie w bazie CEEOL (Central and Eastern European Online Library). Mamy więc do czynienia z hybrydowym modelem udostępniania tekstów. Pokazuje to kolejne możliwości integracji działań bibliotek jako instytucji kultury z zasobami bibliograficznymi, w tym z zawartością systemu iSybislaw.

Barierą $\mathrm{w}$ opisanych powyżej modelach integracji jest nieprzyłączanie się niektórych wydawnictw i bibliotek do idei Otwartej Nauki. Powody nieprzystępowania do Otwartej Nauki są różne, najczęściej wynikają z braku świadomości danych środowisk i komercyjnej działalności instytucji. Podkreślić jednak warto, że idea Otwartej Nauki jest realizowana przez coraz szerszy krąg instytucji, tak w kraju, jak i za granicą. Rośnie też samoświadomość celowości upowszechniania w wolnym dostępie prac z zakresu humanistyki i nauk ścisłych.

Z punktu widzenia użytkowników systemu iSybislaw i osób indeksujących dokumenty najwygodniejszym rozwiązaniem jest model 1. Użytkownik systemu ma bowiem bezpośredni i natychmiastowy dostęp do dokumentu, który ukazuje mu się już po jednym kliknięciu. Można mieć nadzieję, że w przyszłości coraz więcej wydawnictw i platform czasopism będzie wybierać moduł 1 upowszechniania i udostępniania tekstów.

Modelowym przykładem współdziałania systemu informacyjno-wyszukiwawczego (bazy bibliograficznej) i Wydawnictwa IS PAN jako instytucji kultury są przeprowadzone w ciągu ostatnich 3 lat zmiany Instytutu Slawistyki PAN, w którym wszystkie czasopisma dostępne są na jednej platformie czasopism, a monografie instytutowe, dotąd z różnych względów prawnych zamieszczone, lecz niekiedy trudno dostępne w Repozytorium Cyfrowym Instytutów Naukowych (RCIN), otwierane są w repozytorium iReteslaw w module wydawnictwa Instytutu Slawistyki PAN. Od 2014 r. wydawnictwo IS PAN publikuje wszystkie swoje czasopisma na platformie ISS PAS Journals wyłącznie $\mathrm{w}$ formie elektronicznej w otwartym dostępie, a od 2016 r. - również w otwartym dostępie publikowane są monografie i prace zbiorowe $\mathrm{w}$ repozytorium dziedzinowym iReteslaw. Ponadto sukcesywnie otwierane są zasoby zgromadzone w Repozytorium Cyfrowym Instytutów Naukowych.

Do najpilniejszych zadań związanych z rozwojem iSybislawa zaliczyć można konieczność ustandaryzowania formatu metadanych tak, żeby ułatwić pracę związaną z indeksowaniem obiektów bibliograficznych oraz zautomatyzować zapisywanie kwerendy bibliograficznej przy użyciu ogólnodostępnych narzędzi (np. menedżerów bibliografii typu Zotero). Obecnie program ten nie zapisuje prawidłowo metadanych pobranych z bazy. 


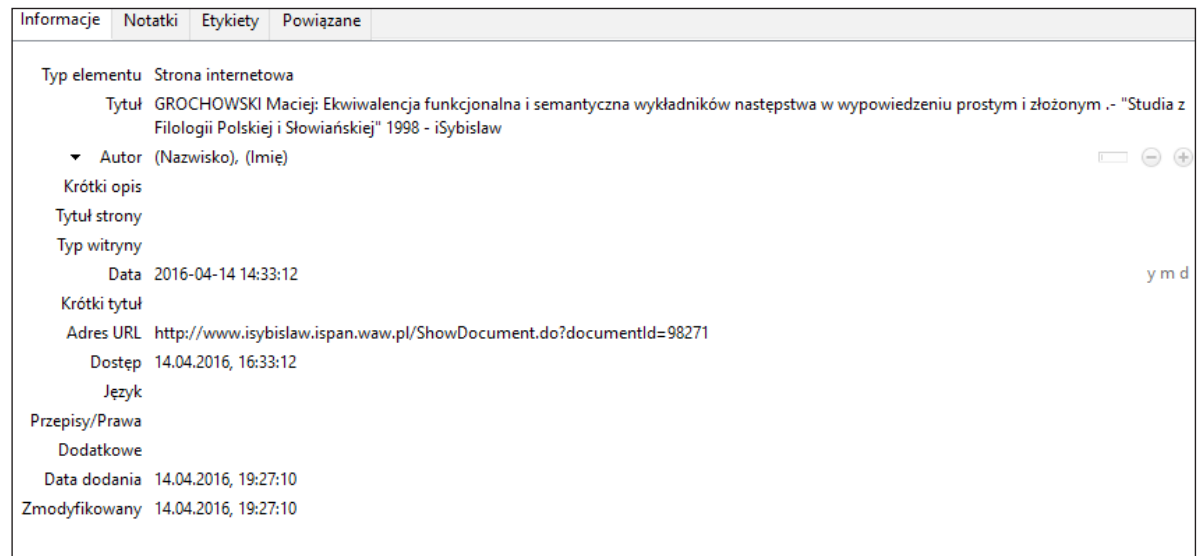

Jak widać na powyższym zrzucie ekranu część metadanych pojawia się nie w tym polu, co trzeba, a część jest odczytywana niepoprawnie (charakter zaindeksowanego dokumentu to artykuł z czasopisma, a nie strona internetowa). Konieczność ręcznego zmieniania danych może być barierą nie do przekroczenia dla współczesnych użytkowników, przyzwyczajonych do szybkich, sprawnych, a przede wszystkim kompatybilnych ze sobą narzędzi cyfrowych. Rozwiązaniem tej niedogodności mogą być działania polegające na zmienieniu systemu informacyjno-wyszukiwawczego iSybislaw w taki sposób, aby był on zgodny z popularnymi otwartymi standardami jak np. Embedded Metadata. Alternatywnie można rozważyć napisanie przy użyciu JavaScript specjalnego translatora, który umożliwi importowanie informacji bibliograficznej do aplikacji. Rozwiązanie takie stanowiłoby pierwszy krok w kierunku automatyzacji wymiany metadanych pomiędzy iSybislawem i innymi portalami jak np. slavistik-portal (https:// slavistik-portal.de/en/).

\section{Podsumowanie}

Powyższe rozważania opatrzone przykładami z funkcjonowania w przestrzeni cyfrowej baz bibliograficznych i instytucji kultury pozwalają wysunąć kilka wstępnych wniosków natury ogólnej oraz pokazać korzyści z wykorzystania jednych i drugich zasobów instytucjonalnych. Integracja poszczególnych zasobów powinna być priorytetem. Pozwala bowiem zwiększyć grono odbiorców informacji slawistycznej. Upowszechnianie informacji i wiedzy m.in. o grupach 
etnicznych lub językowych znajdujących się na peryferiach Słowiańszczyzny, np. Kaszubach, Łużyczanach, Chorwatach gradiszczańskich, Chorwatach moliskich, Bułgarach banackich, Słoweńcach porabskich, daje możliwość włączania do dyskursu społecznego grup wykluczonych. Umożliwia także w nieco inny sposób, bardziej przyjazny społeczeństwu, wykorzystać specjalistyczne, tworzone często na potrzeby naukowe, narzędzia cyfrowe. Przykładem może być tu język słów kluczowych, dzięki któremu można pokazać bogactwo terminologii, rozwój slawistyki na przestrzeni dziejów, trendy we współczesnej Słowiańszczyźnie. Bibliografia wnosi wartość kulturową i traktowana może być jako skarbnica wiedzy danych narodów - w przypadku iSybislawa całej Słowiańszczyzny. Pozwala również na pokazanie tematów i nurtów związanych z badaniami wszystkich języków słowiańskich. Związków - coraz szerszych - językoznawstwa $\mathrm{z}$ innymi naukami, m.in. $\mathrm{z}$ antropologią, socjologią, psychologią, historią, nauką o literaturze, kulturoznawstwem. Integracja w przestrzeni cyfrowej instytucji kultury i bibliografii, którą też należy postrzegać przez pryzmat kulturowy i instytucjonalny, jest więc znakiem naszych czasów.

\section{Bibliografia}

Bojar, Bożenna, Zofia Rudnik-Karwatowa. „Koncepcja nowoczesnego systemu informacji slawistycznej." W Językoznawstwo: prace na XII Międzynarodowy Kongres Slawistów w Krakowie 1998, red. Hanna Dalewska-Greń, Jerzy Rusek, Janusz Siatkowski, 41-47. Warszawa: Energeia, 1998.

Kłoskowska, Antonina. Socjologia kultury. Warszawa: Wydawnictwo Naukowe PWN, 2007.

Ley, Michael, Patrick Reuter. „Maintaining an Online Bibliographical Database: The Problem of Data Quality." Extraction et gestion des connaissances 6, t. 2 (2006): 5-10.

Przastek-Samokowa, Maria. „Czym jest humanistyka cyfrowa? Pole semantyczne pojęcia (zarys)." Zagadnienia Informacji Naukowej. Studia Informacyjne 54, nr 2 (2016): 82-93.

Szlendak, Tomasz, Jacek Nowiński, Piotr Wieczorek. Podręcznik szkoleniowy dotyczacy sektora kultury w Polsce dla wnioskodawców i partnerów Programu „Promowanie różnorodności kulturowej i artystycznej w ramach europejskiego dziedzictwa kulturowego" finansowanego z funduszy EOG 2009-2014. Warszawa 2012. www.eog2016.mkidn. gov.pl/modules/download_gallery/dlc.php?file $=31 \& i d=1419978328 \&$ sid $=14$.

Woźniak-Kasperek, Jadwiga. „Bibliografia w cyfrowej przestrzeni informacyjnej.” Studia z Filologii Polskiej i Stowiańskiej 49 (2014): 14-27. https://doi.org/10.11649/ sfps.2014.005. 
